\title{
PEMENUHAN HAK-HAK PEKERJ A RUMAHAN DALAM POLA USAHA KEMITRAAN ANTARA PERUSAHAAN DENGAN PEKERJ A RUMAHAN
}

\author{
Rizky Putra Edry ${ }^{1 *}$, Aisyah Ayu Musyafah² \\ 1Fakultas Hukum, Universitas Andalas \\ 2Fakultas Hukum, Universitas Diponegoro \\ rizkyputraedry07@gmail.com
}

\begin{abstract}
The protection of the rights of home-based workers is still not common as a discourse in labor law, although there have been constitutional guarantees regarding the right to fair treatment in employment relations. Partnership is one of the ways done by companies to be able to employ home-based workers for efficiency reasons. This research is intended to examine how the guarantees of home-based workers 'rights, the partnership to the home-based workers and their impact.The method used is empirical judicial. The results of the research are that the partnership cannot be applied between the companies and home-based workers because it's not having a legal basis and it will also have an impact on the non-fulfillment of the rights of homebased workers.
\end{abstract}

Keywords: Home Based Worker; Labor Law; Workers Right; Partnership.

\begin{abstract}
ABSTRAK
Perlindungan hak-hak pekerja rumahan masih belum jamak menjadi diskursus dalam hukum ketenagakerjaan meskipun UUD 1945 telah menjamin hak atas perlakuan yang adil dalam hubungan kerja. Pola usaha kemitraan adalah salah satu cara yang dilakukan oleh perusahaan agar dapat mempekerjakan pekerja rumahan dengan alasan efisiensi. Penelitian ini ditujukan untuk mengkaji jaminan hak-hak pekerja rumahan, penerapan pola usaha kemitraan pada pekerja rumahan dan dampaknya. Adapun metode yang digunakan adalah yudiris-empiris. Hasil penelitian adalah pola usaha kemitraan tidak dapat diterapkan dalam relasi perusahaan dengan pekerja rumahan karena selain tidak memiliki dasar hukum juga berdampak pada tidak terpenuhinya hak-hak pekerja rumahan.
\end{abstract}

Kata Kunci: Pekerja Rumahan; Hukum Ketenagakerjaan; Hak-hak Pekerja; Kemitraan.

\footnotetext{
${ }^{*}$ Corresponding Author
} 
Jurnal Pembangunan Hukum Indonesia

Volume 1, Nomor 2, Tahun 2019
Program Studi Magister Ilmu Hukum Fakultas Hukum Universitas Diponegoro

\section{A. PENDAHULUAN}

Diskursus mengenai perlindungan hak-hak pekerja rumahan (home-based worker) masih belum terlalu menjadi perhatian dalam pembahasan hukum ketenagakerjaan di Indonesia. Hal ini pada akhirnya juga berdampak pada minimnya, bahkan hampir tidak ada, perlindungan hukum berkaitan dengan hak-hak pekerja rumahan. Padahal, Pasal 27 ayat (2) dan Pasal 28D ayat (2) UUD NRI 1945, yang menegaskan bahwa setiap orang berhak atas pekerjaan serta perlakuan yang adil dan layak dalam hubungan kerja, seharusnya dimaknai sebagai initial push yang dapat digunakan untuk membentuk kebijakan serta praktik berhukum yang melindungi pekerja rumahan.

Pekerja rumahan secara sederhana dapat didefinisikan sebagai pekerja dari suatu perusahaan yang melakukan kegiatan produksi di luar lingkungan perusahaan (di rumah sendiri ataupun di tempat perkumpulan komunitas). Meskipun sebenarnya pekerjaan tersebut dapat dilakukan di lingkungan perusahaan (oleh pekerja formal), namun beberapa perusahaan lebih memilih untuk mengalihkan pekerjaan tersebut ke pekerja rumahan sehingga tidak perlu merekrut terlalu banyak pekerja formal karena dipandang akan meningkatkan cost produksi. Beberapa contoh pekerjaan yang kerap dikerjakan pekerja rumahan antara lain: pengolahan makanan; finishing produk garmen; atau proses pengepakan (packaging).

Dalam ideologi kapitalisme yang mengandalkan supremasi pasar dan maksimalisasi laba, tentu prkatik mempekerjakan pekerja rumahan bukan tanpa alasan atau bukan untuk menciptakan the trickle down effect sebagaimana yang dicitaciatakan pada awalnya. Eksploitatif adalah watak dari kapitalsime. Oleh karenanya, pilihan untuk mempekerjakan pekerja rumahan tentu juga akan berdampak pada hak-hak pekerja rumahan. Secara lebih komprehensif, International Labour Organization (ILO) menyatakan terdapat setidaknya 12 permasalahan yang sering dihadapi oleh pekerja rumahan di Indonesia, antara lain: (1) Tak ada perjanjian kerja tertulis/kontrak; (2) Tak ada posisi tawar; (3) Upah di bawah UMK; (4) Jam kerja yang seringkali panjang; (5) Tidak ada jaminan pekerjaan atau pendapatan yang tak tentu; (6) Tidak ada jaminan sosial; (7) Tidak ada perlindungan kesehatan dan keselamatan kerja; (8) Tidak ada perlindungan maternal; (9) Tidak ada mekanisme untuk penyelesaian perselisihan; (10) Hambatan untuk membentuk atau menjalankan aktivitas serikat pekerja; (11) Keterlibatan pekerja anak; dan (12) Ikut menanggung sebagian biaya produksi dan resiko yang umumnya merupakan tanggung jawab pemberi kerja.

Berdasarkan hasil penelitian pemetaan pekerja rumahan di Indonesia yang dilakukan oleh ILOMAMPU pada tahun 2015, dalam konteks upah dan jam kerja pekerja rumahan di Jawa Tengah, didapatkan data sebagai berikut:

Tabel 1. Upah dan J am Kerja Rata-rata Pekerja Rumahan di Provinsi J awa Tengah Berdasarkan Sektor Pekerjaan 
Jurnal Pembangunan Hukum Indonesia

Volume 1, Nomor 2, Tahun 2019
Program Studi Magister Ilmu Hukum Fakultas Hukum Universitas Diponegoro

\begin{tabular}{lll}
\hline Sektor Pekerjaan & $\begin{array}{l}\text { Upah rata- } \\
\text { rata (per } \\
\text { bulan) }\end{array}$ & $\begin{array}{l}\text { J am kerja } \\
\text { rata-rata (per } \\
\text { minggu) }\end{array}$ \\
\hline $\begin{array}{l}\text { Pengolahan } \\
\text { makanan }\end{array}$ & Rp. 267.121 & 30,7 jam \\
\hline $\begin{array}{l}\text { Tekstil (pemintalan, } \\
\text { tenun, pencelupan) }\end{array}$ & Rp. 449.015 & 39,4 jam \\
\hline $\begin{array}{l}\text { Pakaian jadi } \\
\text { (menjahit baju) }\end{array}$ & Rp. 480.163 & 38,5 jam \\
\hline Kulit, barang kulit & Rp. 430.728 & 57,6 jam \\
dan alas kaki & & \\
\hline Pengolahan kayu, & Rp. 342.538 & 37,3 jam \\
bambu dan rotan & & \\
\hline Furnitur & Rp. 445.888 & 31,2 jam \\
\hline Manufaktur lain & Rp. 294.749 & 33,6 jam \\
\hline
\end{tabular}

Berdasarkan tabel diatas, terlihat bahwa jam kerja rata-rata per minggu dari pekerja rumahan hampir menyamai jam kerja pekerja formal sebagaimana diatur oleh Undang-undang Nomor 13 Tahun 2003 tentang Ketenagakerjaan, yaitu 40 jam/minggu. Bahkan, di sektor kulit dan alas kaki, jam kerja rata-rata pekerja rumahan hampir satu setengah kali lipat jam kerja yang ditentukan oleh undang-undang ketenagakerjaan. Namun demikian, upah yang diperoleh pekerja rumahan masih begitu rendah.

Keberadaan pekerja rumahan dalam rantai pasok global (global supply chain) merupakan dampak dari fleksibilitas pasar tenaga kerja. Indrasari Tajandraningsih menyatakan bahwa pasar tenaga kerja fleksibel merupakan a strategy adopted by capital to minimize the negative impact of economic shocks basically by hiring and firing workers (Tjandraningsih, 2012). Sementara itu, Benny Hari Juliawan dengan mengutip Economist menyatakan bahwa kriteria pasar tenaga kerja fleksibel adalah in which it is easy and inexpensive for firms to vary the amount of labor they use (Juliawan, 2010).

Dengan adanya praktik pasar tenaga kerja fleksibel, maka hubungan kerja antara pemberi kerja dengan pekerja didesain selentur mungkin dengan konsekuensi mengorbankan hak atas pekerjaan yang merupakan bagian dari hak asasi manusia. Bahkan, dalam konteks pekerja rumahan, hubungan kerja dibuat selentur mungkin, sehingga tak jarang pekerja rumahan tidak mengetahui pekerjaan yang dikerjakannya untuk perusahaan yang mana.

Triana Sofiani menyatakan terdapat dua jenis pekerjaan rumahan, yaitu Putting Out System (POS) dan Self Employed (SE). Model POS adalah pekerjaan yang dilakukan dengan cara mengambil pekerjaan dari pemberi kerja dan langsung dibawa kerumah untuk dikerjakan sendiri. Sedangkan model SE dilakukan dengan cara mendapatkan order yang dibawa dari pemberi kerja, atau yang biasa diitilahkan dengan pengepul, untuk dibagi-bagikan kepada POS (Sofiani, 2010).

Sementara itu, dalam hasil penelitian yang dilakukan Yayasan Annisa Swasti (Yasanti), terdapat beberapa pola rantai produksi yang pekerja rumahan menjadi bagian didalamnya sebagaimana diilustrasikan dalam gambar berikut: 
Jurnal Pembangunan Hukum Indonesia

Volume 1, Nomor 2, Tahun 2019

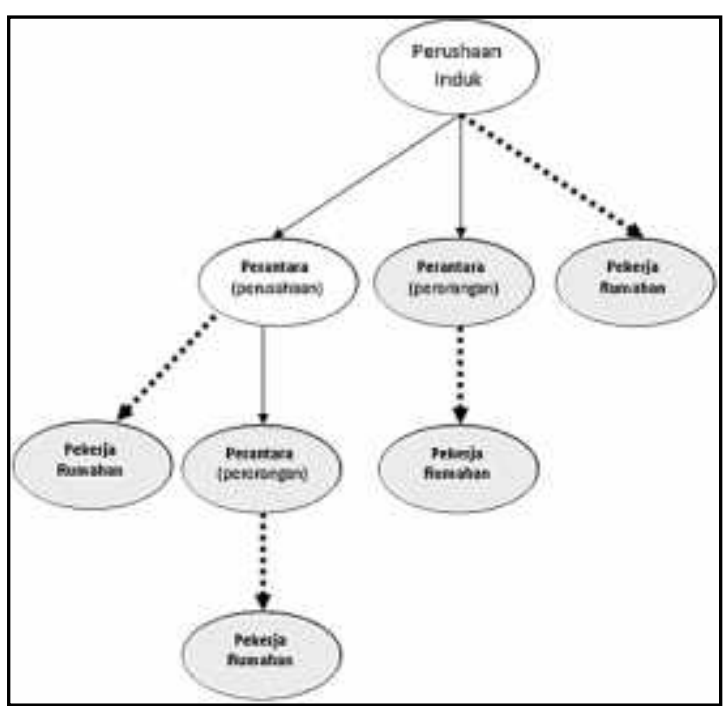

Gambar 1. Ragam Alur Rantai Produksi dari

Perusahaan ke Pekerja Rumahan dengan Satu

Perusahaan Induk

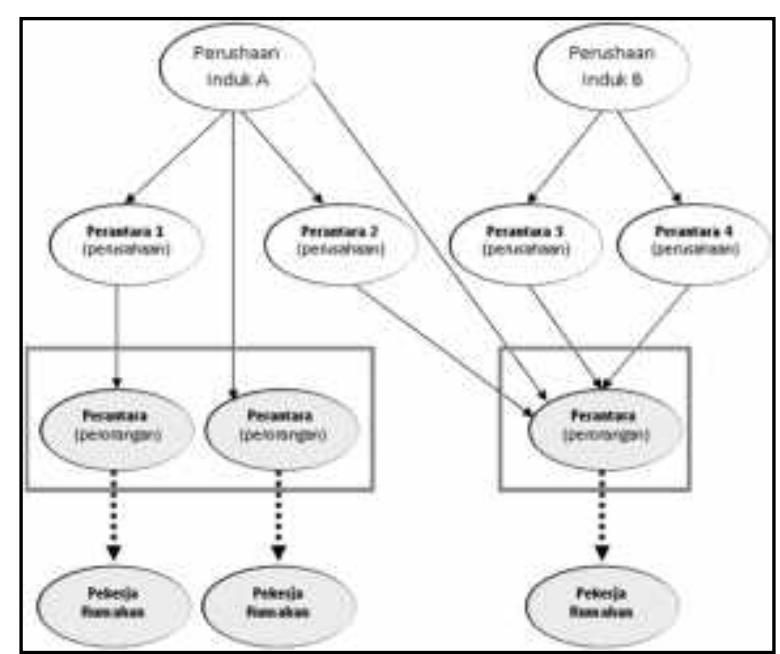

Gambar 2. Ragam Alur Rantai Produksi dari

Perusahaan ke Pekerja Rumahan dengan Lebih dari

Satu Perusahaan Induk

Melalui gambar diatas, tampak lebih jelas bagaimana posisi pekerja rumahan dalam rantai produksi, baik yang menggunakan model POS maupun SE. Bahkan dalam Gambar 2, terlihat pekerja rumahan dapat bekerja untuk lebih dari satu perusahaan induk. Meskipun dalam model POS, rantai produksi cenderung tampak jelas, namun
Program Studi Magister IImu Hukum Fakultas Hukum Universitas Diponegoro

pekerja rumahan tetap saja diposisikan bukan sebagai pekerja. Salah satunya adalah melalui penerapan pola usaha kemitraan antara Perusahaan dengan Pekerja Rumahan.

Salah satu perusahaan yang menggunakan pola kemitraan kepada pekerja rumahan adalah PT Ara Shoes Indonesia yang berlokasi di Jalan PTP XVIII Ngobo, Karangjati, Bergas, Kabupaten Semarang. PT Ara Shoes Indonesia merupakan perusahaan yang berpusat di Jerman dengan core business memproduksi alas kaki. Berdasarkan wawancara yang dilakukan pada tanggal 14 Februari 2019 kepada Rima Astuti sebagai staf Yasanti kantor Ungaran, Yasanti mencatat bahwa PT Ara Shoes Indonesia mempekerjakan 530 orang pekerja rumahan. Terlihat, bahwa PT Ara Shoes Indonesia sebagai multi national coporation dan industri besar, mempekerjakan pekerja rumahan sebagai bagian dari rantai produksi. Jumlah pekerja rumahan yang dipekerjakan pun ternyata sangat besar. Untuk itu, perlu mengkaji bagaimana pemenuhan ha-hak pekerja rumahan yang direkrut melalui pola usahan kemitraan oleh PT Ara Shoes Indonesia.

Dalam pembahasan, akan digunakan teori justice as fairness sebagaimana diutarakan oleh John Rawls. Teori ini sangat relevan dengan konteks Indonesia. Sejak peletakan dasar negara Indonesia yang merdeka, Pancasila merupakan sebuah konsepsi keadilan yang bersifat 'netral' terhadap pelbagai keyakinan dan pandangan hidup. Konsepsi justice as fairness yang termuat di dalam Pancasila merupakan sebuah konsepsi yang memperoleh dukungan melalui konsensus tumpangsusun 
(overlapping concensus) dari doktrin-doktrin filsafat, agama, dan moral yang reasonable (Alwino, 2016).

Dalam teori ini, sebagaimana dikutip oleh Damanhuri Fattah, terdapat dua prinsip utama, yaitu: (1), setiap orang memiliki hak yang sama atas kebebasan-kebebasan dasar yang paling luas, seluas kebebasan yang sama bagi semua orang; dan (2), ketimpangan sosial dan ekonomi mesti diatur sedemikian rupa, sehingga: (a) diperoleh manfaat sebesar-besarnya bagi anggota masyarakat yang paling tidak beruntung dan (b) jabatan harus dibuka bagi semua orang dalam keadaan dimana adanya persamaan kesempatan yang adil (Fattah, 2013).

John Rawls menjelaskan mengenai justice as fairness terbagi pada dua prinsip, yaitu :

"First Principle, Each person has the same indefeasible claim to a fully adequate scheme of equal basic liberties, which scheme is compatible with the same scheme of liberties for all; and Second Principle: Social and economic inequalities are to satisfy two conditions: a) They are to be attached to offices and positions open to all under conditions of fair equality of opportunity; b) They are to be to the greatest benefit of the least-advantaged members of society (the difference principle)" (Dutta, 2017).

Perlindungan pekerja rumahan masih belum mendapat banyak perhatian dari UU Ketenagakerjaan meskipun hak mendapat perlakuan adil dalam bekerja manjadi jaminan dari konstitusi negara kepada seluruh rakyatnya. Pola usaha kemitraan adalah salah satu cara yang dilakukan oleh perusahaan agar dapat mempekerjakan pekerja rumahan dengan alasan efisiensi, namun pada pola seperti ini pekerja rumahan seolah diposisikan bukan sebagai pekerja. Hal ini karena lenturnya hubungan kerja antara pemberi kerja dengan pekerja nya.

Dalam penelitian ini, akan dijawab beberapa permasalahan sebagai berikut:

a. Bagaimana jaminan hukum terhadap hak-hak pekerja rumahan?

b. Bagaimana praktik penerapan pola usaha kemitraan antara perusahaan dan pekerja rumahan dan dampaknya bagi pemenuhan hak pekerja rumahan?

c. Apa langkah yang dapat dilakukan dalam menjamin pemenuhan hak-hak pekerja rumahan?

Sebagaimana tulisan ini sampaikan diawal, diskursus mengenai pekerja rumahan masih minim dalam hukum ketenagakerjaan di Indonesia. Adapun penelitian terdahulu mengenai tema ini pernah dilakukan oleh Triana Sofiani. Meskipun secara singkat membahas posisi hukum pekerja rumahan dalam hukum ketenagakerjaan di Indonesia, namun dilakukan dengan sangat singkat dan menggunakan beberapa aturan hukum yang sudah tidak berlaku lagi, bahkan pada saat penelitian tersebut dibuat. Hal ini dikarenakan fokus utama dari penelitian tersebut adalah mengenai tinjauan feminisme terhadap keberadaan pekerja rumahan (Sofiani, 2010)

Alwino dalam jurnalnya membahas keadilan seperti yang dibahas dalam Penelitian ini namun lebih luas mengenai teori-teori keadilan yang mendasar dan tidak mengerucut mengenai pekerja rumahan (Alwino, 2016).

Pada penelitian yang dilaksanakan oleh Benny Hari Juliawan, sama-sama membahas mengenai 
hak-hak pekerja sebagai upaya perlindungan, namun tidak mengerucut pada pembahasan pekerja rumahan seperti pada penelitian ini (Juliawan, 2010)

Penelitian yang dilakukan oleh Arnold dan rekannya Bonglovy juga membahas hal yang hampir sama namun lebih melebar kearah politik dan kebijakan, berbeda dengan Penelitian ini yang lebih kearah hukum ketenagakerjaannya (Arnold, \& Bonglovy, 2013).

Penelitian Sampurnaa Dutta juga membahas mengenai keadilan yang menjadi tujuan Penelitian ini, namun ia membahas keadilan secara luas tidak mengarah kepada hukum ketegakerjaan (Dutta, 2017)

\section{B. METODE PENELITIAN}

Metode yang digunakan dalam penelitian ini adalah yuridis-empiris dengan melihat bagaimana pola usaha kemitraan dijalankan pada relasi antara pekerja rumahan dengan perusahaan. Selain itu, juga akan diteliti mengenai bagaimana kedudukan hukum pekerja rumahan dalam hukum positif.

Adapun data yang digunakan adalah data primer yaitu data yang diperoleh secara langsung dari penelitian lapangan (field research) melalui interview atau wawancara, dengan responden yang merupakan pekerja rumahan dengan pola usaha kemitraan. Kemudian, juga akan digunakan data sekunder untuk menunjang data primer terdiri atas bahan hukum primer dan bahan hukum sekunder dan tersier. Setelah dilakukan pengumpulan data baik data yang diperoleh dari penelitian kepustakaan maupun data yang diperoleh dari penelitian lapangan, data tersebut akan diedit terlebih dahulu. Selanjutnya data tersebut dianalisis secara kualitatif dengan jalan menafsirkan guna mendapatkan kejelasan mengenai penerapan pola usaha kemitraan dalam relasi perusahaan dan pekerja rumahan serta bagaimana jaminan terhadap hak-hak pekerja rumahan.

\section{HASIL DAN PEMBAHASAN}

\section{J aminan Hak-hak Pekerja Rumahan}

Eksistensi Pasal 27 ayat (2) dan Pasal 28D ayat (2) UUD NRI 1945 merupakan penegas bahwa posisi pekerja menjadi perhatian penting secara konstitusional. Jimly Asshiddiqie menyatakan bahwa karena keberadaan pasal-pasal ini, UUD NRI 1945 dapat disebut sebagai the Workers Constitution. Adapun isi dari Pasal 27 ayat (2) UUD NRI 1945 adalah, "Tiap-tiap warga negara berhak atas pekerjaan dan penghidupan yang layak bagi kemanusiaan", sementara Pasal 28 ayat (2) UUD NRI 1945 meyatakan bahwa, "Setiap orang berhak untuk bekerja serta mendapat imbalan dan perlakuan yang adil dan layak dalam hubungan kerja".

Namun demikian, permasalahan ketenagakerjaan masih kerap terjadi, utamanya dikarenakan oleh penerapan pasar tenaga kerja fleksibel atas prakarsa lembaga-lembaga finansial global sebagai prasyarat untuk memperoleh pinjaman utang untuk pembangunan.

Dalam kaitannya dengan pekerja rumahan, Pemerintah tampak membiarkan terjadinya praktikpraktik mempekerjakan pekerja rumahan untuk industri besar tanpa payung hukum yang jelas. 
Undang-Undang Ketenagakerjaan dalam pekerjaan yang dilakukannya. Kemudian, berkenaan operasionalisasinya seringkali diidentikkan dengan dengan hubungan kerja, maka dapat dilihat bahwa pekerja formal. Sementara, pekerja rumahan, sebagaimana telah dijelaskan sebelumnya, seringkali diposisikan sebagai pekerja informal yang berada pada sektor formal.

Meskipun demikian, Undang-Undang Ketenagakerjaan, secara normatif, tampak telah cukup kuat untuk melindungi pekerja rumahan. Hal ini dapat dilakukan dengan menggunakan penafsiran sistematis terhadap Undang-Undang Ketenagakerjaan. Sebagaimana dinyatakan oleh Jimly Asshiddiqie dengan mengutip beberapa pakar lain, penafsiran sistematis didefinisikan sebagai, "penafsiran undang-undang sebagai bagian dari keseluruhan sistem perundang-undangan" (Asshiddiqie, 2009). Oleh karena itu, ketentuan dalam Undang-Undang Ketenagakerjaan haruslah dimaknai sebagai regulasi yang hendak mewujudkan perlakuan yang adil dan layak dalam hubungan kerja sebagaimana dikehendaki oleh Konstitusi.

Dalam kaitannya dengan pemenuhan hak-hak pekerja rumahan, Pasal 1 angka 3 undang-undang a quo menyatakan bahwa, "Pekerja/buruh adalah adalah setiap orang yang bekerja dengan menerima upah atau imbalan dalam bentuk lain". Kemudian, pasal 1 angka 15 menyatakan, "Hubungan kerja adalah hubungan antara pengusaha dengan pekerja/buruh berdasarkan perjanjian kerja, yang mempunyai unsur pekerjaan, upah dan perintah."

Merujuk pada ketentuan Pasal tersebut, dapat terlihat bahwa pekerja rumahan adalah pekerja karena pekerja rumahan menerima upah untuk setiap unsur-unsur hubungan kerja terpenuhi dalam relasi antara pekerja rumahan dengan perusahaan, yaitu: (1) unsur pekerjaan, mutlak ada karena tidak mungkin pekerja rumahan tidak melakukan pekerjaan apa untuk perusahaan, (2) unsur upah, meskipun nominalnya kerap sangat rendah dan tidak sesuai UMK, namun pekerja rumahan menerima upah untuk setiap pekerjaan yang dilakukan, dan (3) unsur perintah, pada dasarnya apa yang dikerjakan pekerja rumahan adalah berdasarkan perintah dari perusahaan agar dapat mendapatkan upah.

Kemudian, berkenaan dengan syarat adanya perjanjian kerja untuk membuktikan ada atau tidaknya hubungan kerja, dapat merujuk pada Penejelasan Pasal 51 ayat (1) Undang-Undang Ketenagakerjaan yang menyatakan bahwa perjanjian kerja dimungkinan untuk dibuat secara lisan. Artinya, kesepakatan antara pekerja rumahan dan perusahaan tetap dianggap sebagai perjanjian kerja meskipun tidak dalam bentuk tertulis.

Penjelasan diatas diperkuat dengan pandangan Guus Heerma van Voss, bahwa:

"Bila kita bandingkan pengertian kontrak kerja Eropa dengan versi Indonesia [...], maka dapat dikatakan keduanya identik berkenaan dengan dua elemen esensial, yaitu 'kerja' dan 'upah/imbalan'. Tetapi elemen ketiga, otoritas tidak secara eksplisit merupakan bagian dari definisi kontrak kerja versi Indonesia. Hal ini dapat dijelaskan dengan menyatakan bahwa pembuat undang-undang Indonesia kiranya hendak memberikan definisi dengan cakupan yang luas, sedemikian sehingga dapat mencakup segala bentuk kerja paruh waktu atau sementara sekalipun otoritas pemberi 
Jurnal Pembangunan Hukum Indonesia

Volume 1, Nomor 2, Tahun 2019
Program Studi Magister Ilmu Hukum Fakultas Hukum Universitas Diponegoro kerja tidak tampak sertamerta di dalamnya" (Voss, 2012).

Dengan diperkuat oleh pandangan Voss bahwa hukum ketenagakerjaan di Indonesia dapat mencakup segala bentuk kerja termasuk paruh waktu, maka ketentuan Pasal 1 angka 3 dan Pasal 1 angka 15 Undang-undang Ketenagakerjaan telah terpenuhi dalam relasi antara pekerja rumahan dengan perusahaan, maka pekerja rumahan merupakan subjek dalam Undang-Undang Ketenagakerjaan. Oleh karenanya, ketentuan di dalam Undang-undang Ketenagakerjaan dapat berlaku kepada pekerja rumahan maupun perusahaan yang mempekerjakan pekerja rumahan.

Adapun hak-hak pekerja rumahan yang daitur dalam Undang-undang Ketenagakerjaan antara lain:

a. Non-diskriminasi (Pasal 5 dan Pasal 6)

b. Upah yang layak (Pasal 88 - Pasal 98)

C. Jaminan sosial (Pasal 99)

d. Waktu kerja layak (Pasal 77 - Pasal 85)

e. Jaminan K3 (Pasal 86 dan Pasal 87)

f. Cuti Haid (Pasal 81)

g. Hak Maternitas (Pasal 82 dan Pasal 83)

Selain hak-hak tersebut, karena pekerja rumahan adalah pekerja dan menjadi subjek hukum ketenagakerjaan, maka hak-hak pekerja yang ada dalam Undang-Undang Nomor 21 Tahun 2000 tentang Serikat Pekerja/Serikat Buruh dan UndangUndang Nomor 2 Tahun 2004 tentang Penyelesaian Perselisihan Hubungan Industrial juga merupakan hak pekerja rumahan. Hal ini penting untuk: (1) memberikan hak berserikat dan berunding bagi pekerja rumahan kepada perusahaan, dan (2) memberikan kepastian mengenai mekanisme perselisihan perburuhan yang potensial terjadi antara pekerja rumahan dengan perusahaan.

\section{Praktik Penerapan Pola Usaha Kemitraan} antara Perusahaan dan Pekerja Rumahan dan Dampaknya bagi Pemenuhan Hak Pekerja

\section{Rumahan}

Pasar tenaga kerja yang fleksibel telah mendorong informalisasi pasar kerja. Hubungan kerja yang formal dan cenderung kaku tidak begitu diminati karena kuatnya jaminan hak-hak buruh didalamnya, utamanya buruh perempuan. The era of flexibility is also an era of more generalized insecurity and precariousness, in which many more men as well as women have been pushed into precarious forms of labor (Arnold, \& Bonglovi, 2013). Hal ini juga berdampak kepada pekerja rumahan,

Dengan adanya kondisi dualisme pada pasar kerja di Indonesia, yaitu segmentasi formal dan informal, posisi pekerja rumahan berada diantara sektor formal dan informal. Dikatakan sebagai bagian dari sektor formal karena pekerja rumahan umumnya bekerja pada perusahaan-perusahaan besar, bahkan MNC/TNC, yang masuk ke dalam spesifikasi sektor ekonomi formal. Sementara, dikatakan informal dikarenakan dalam praktiknya, pekerja rumahan belum memiliki kerangka hukum yang tegas dalam rangka jaminan hak-hak normatif. Dengan meminjam istilah yang digunakan Lourdes Benería dan Maria Floro, pekerja rumahan merupakan pekerja informal yang terhubung pada sektor formal (Benería \& Floro, 2005). 
Salah satu bentuk konret dari hal tersebut adalah adanya penerapan pola usaha kemitraan dalam relasi antara perusahaan dengan pekerja rumahan. Penggunaan pola usaha kemitraan ini terlihat berbeda dari aturan hukum yang telah ada, yaitu Undang-Undang Ketenagakerjaan. Namun demikian, perlu dilihat kiranya bagaimana realitas pemenuhan hak-hak pekerja rumahan dalam pola usaha kemitraan antara perusahaan dengan pekerja rumahan serta pandangan hukum mengenai legalitasnya.

Berdasarkan wawancara tanggal 15 Oktober 2018 yang dilakukan kepada Giyati pada sebagai mantan pekerja rumahan PT Ara Shoes Indonesia nomor induk HW 801194 yang di PHK pada Agustus 2016 tanpa alasan yang jelas dari perusahaan, selama ia bekerja pada perusahaan yang berada di Kabupaten Semarang tersebut, diterapkan pola usaha kemitraan antara pekerja rumahan dengan perusahaan. Hal ini dibuktikan dengan adanya perjanjian yang pada bagian kepala perjanjian tertulis "Perjanjian Kemitraan". Namun, perjanjian ini baru ditandatangani oleh Giyati pada tahun 2014, atau lima tahun setelah ia menjadi pekerja rumahan di perusahaan tersebut. Pada saat penandatangan perjanjian, Giyati mengaku tidak paham untuk apa perjanjian tersebut karena ia hanya diminta menandatangani saat mengambil orderan sepatu yang akan ia jahit.

Secara garis besar, Perjanjian Kemitraan antara PT Ara Shoes Indonesia dengan pekerja rumahan mencoba membuat konstruksi bahwa pekerja rumahan dengan perusahaan berada dalam posisi setara, dan oleh karenanya dapat disebut sebagai mitra. Namun demikian, bentuk perjanjian tersebut merupakan perjanjian baku sehingga pekerja rumahan tidak berada dalam posisi setara dengan perusahaan dalam menentukan isi perjanjian.

Dalam perjanjian tersebut juga dinyatakan bahwa pekerja rumahan diharuskan tunduk dan melaksanakan seluruh ketentuan yang telah diatur dalam tata tertib maupun ketentuan lain yang menjadi keputusan Direksi atau Manajemen perusahaan. Selain itu, Perjanjian Kemitraan tidak mengatur mengenai jaminan sosial yang diperuntukkan bagi pekerja rumahan. Kecelakan kerja hanya ditanggung jika terjadi saat di dalam perusahaan.

Berkenaan dengan upah, dilakukan berdasarkan satuan hasil. Kemudian, pekerja rumahan juga dinyatakan tidak terikat dengan jam kerja, namun diharuskan untuk menyelesaikan pekerjaannya maksimal selama dua hari.

Dalam praktiknya, berkaitan dengan beban kerja yang diberikan oleh PT Ara Shoes Indonesia kepada pekerja rumahan, Giyati menyatakan diharuskan menjahit bagian sole dan upper sepatu sebanyak satu parti (10 pasang) dalam jangka waktu dua hari. Jika telah selesai, sepatu-sepatu tersebut dikembalikan kepada petugas yang ditempatkan perusahaan pada pos-pos tertentu sembari kembali mengambil stok sepatu yang akan dijahit dengan jumlah yang sama. Untuk menjahit satu parti sepatu, rata-rata waktu yang dibutuhkan adalah 20 jam. Dengan demikian, pekerja rumahan pada PT Ara 
Shoes Indonesia rata-rata bekerja 10 jam setiap harinya. Bahkan, jika permintaan sedang banyak, para pekerja rumahan bisa dibebankan untuk menjahit tiga parti sepatu. Jika keadaannya demikian, para pekerja rumahan harus meminta bantuan anggota keluarga atau tetangga untuk menyelesaikan penjahitan sepatu tersebut. Adapun upah yang diterima oleh pekerja rumahan PT Ara Shoes Indonesia, fluktuatif. Hal ini karena upah diberikan berdasarkan satuan hasil. Selain itu, juga tidak ada kompensasi dari perusahaan berkaitan dengan biaya produksi ataupun transportasi yang harus dikeluarkan Giyati selama mengerjakan sepatu, semisal air dan listrik.

Pada Februari 2016 misalnya, berdasarkan slip gaji yang diterima Giyati, ia berhasil menyelesaikan 80 pasang dalam satu bulan. Artinya, dibutuhkan 160 jam untuk menyelesaikan penjahitan sepatu tersebut. Artinya, jika diarat-ratakan, 40 jam waktu Giyati terpakai untuk melakukan pekerjaan selama seminggu. Meskipun waktu kerja yang dibutuhkan sebanding dengan ketentuan Pasal 77 ayat (2) Undang-Undang Nomor 13 Tahun 2003 tentang Ketenagakerjaan (selanjutnya ditulis Undang-undang Ketenagakerjaan), namun upah yang diteima Giyati selama satu bulan hanya sebesar Rp. 339.000. Padahal, upah minimun kabupaten (UMK) Semarang pada saat itu mencapai Rp. 1.610.000,-. dan oleh karenanya, bertentangan dengan Pasal 157 ayat (3) Undang-Undang Ketenagakerjaan yang mengatur bahwa, "Dalam hal upah pekerja/buruh dibayarkan atas dasar perhitungan satuan hasil, potongan/borongan atau komisi, maka penghasilan sehari adalah sama dengan pendapatan rata-rata per hari selama 12 (dua belas) bulan terakhir, dengan ketentuan tidak boleh kurang dari ketentuan upah minimum provinsi atau kabupaten/kota".

Jika memperhatikan jam kerja dan upah yang diterima oleh Giyati, hal ini tampak sebanding dengan data pada Tabel 1.

Berkaitan dengan pemberlakuan pola usaha kemitraan oleh PT Ara Shoes Indonesia kepada pekerja rumahan, perlu diperhatikan ketentuan Undang-Undang Nomor 20 tahun 2008 tentang Usaha Mikro, Kecil, dan Menengah. Dalam Pasal 1 angka 13 undang-undang a quo dinyatakan bahwa, "Kemitraan adalah kerjasama dalam keterkaitan usaha, baik langsung maupun tidak langsung, atas dasar prinsip saling memerlukan, mempercayai, memperkuat, dan menguntungkan yang melibatkan pelaku Usaha Mikro, Kecil, dan Menengah dengan Usaha Besar". Kemudian, pertama-tama, penting untuk melihat apakah Giyati memenuhi kriteria sehingga dapat digolongkan sebagai usaha mikro, kecil, atau menengah. Didefinisikan dalam Pasal 1 angka 1 sebagai, "usaha produktif milik orang perorangan dan/atau badan usaha perorangan yang memenuhi kriteria Usaha Mikro sebagaimana diatur dalam Undang-Undang ini".

Lebih lanjut, kriteria mengenai usaha mikro diatur dalam Pasal 6 ayat (1) Undang-Undang ini. Selengkapnya dinyatakan:

"Kriteria Usaha Mikro adalah sebagai berikut:

a.memiliki kekayaan bersih paling banyak Rp50.000.000,00 (lima puluh juta rupiah) tidak 
termasuk tanah dan bangunan tempat usaha; atau

b.memiliki hasil penjualan tahunan paling banyak Rp300.000.000,00 (tiga ratus juta rupiah)".

Dinyatakan oleh Giyati, ia tidak memiliki usaha mikro karena tidak memenuhi kriteria tersebut. Selain itu, ia juga tidak memiliki izin usaha mikro kecil (IUMK) sebagaimana diatur oleh Perpres Nomor 98 Tahun 2014 tentang Perizinan Usaha Mikro dan Kecil. Karena kriteria sebagai usaha mikro tidak terpenuhi secara yuridis maupun kriteria ekonomi, tidak perlu lagi kiranya untuk melihat apakah Giyati memenuhi kriteria sebagai usaha kecil ataupun menengah, karena standarnya lebih tinggi dibanding usaha mikro. Berdasarkan penjelasan di atas, dapat dilihat bahwa pola usaha kemitraan yang diterapkan oleh PT Ara Shoes Indonesia kepada para pekerja rumahan tidak sesuai dengan hukum yang berlaku.

Dengan demikian, dapat disimpulkan setidaknya empat dampak yang dialami oleh pekerja rumahan dalam pola usaha kemitraan, yaitu: (1) Terjadinya diskriminasi kepada pekerja rumahan dalam hubungan kerja; (2) Tidak disediakannya jaminan sosial oleh perusahaan, (3) Rendahnya upah bahkan kurang dari setengah jumlah UMK sementara jam kerja relatif sama, dan (4) Tidak adanya jaminan K3.

Selain itu, sebagaimana yang dituturkan oleh Giyati, bahwa ia diminta begitu saja untuk menandatangani perjanjian kemitraan tersebut pada 2014 pada saat mengambil orderan sepatu dan tanpa dijelaskan kepadanya isi perjanjian tersebut, tindakan PT Ara Shoes Indonesia dalam hal ini dapat dikategorikan sebagai penyalahgunaan keadaan (misbruik van omstandigheden).

Penyalahgunaan keadaan merupakan perkembangan dari hukum kontrak yang berkaitan dengan kebabasan berkontrak. Penyalahagunaan keadaan dapat terjadi karena adanya dua faktor, antara lain: (1) penyalahgunaan keunggulan ekonomi, dan (2) penyalahgunaan keunggulan kejiwaan (Paparang, 2016).

Sebenarnya, misbruik van omstandigheden berawal dari pembaharuan Nieuw Burgelijk Wetboek (NBW). Namun dalam praktik di Indonesia, Mahkamah Agung menggunakan dalil misbruik van omstandigheden untuk memutus perkara. Misal, dalam Putusan Nomor 1843 K/PDT/2012.

Secara yuridis, terlihat bahwa penerapan pola usaha kemitraan antara perusahaan dengan pekerja rumahan tidak memiliki dasar hukum serta telah bertentangan dengan asas misbruik van omstandigheden. Kemitraan hanya dimungkinkan dilakukan antara usaha besar dengan usaha mikro, kecil, maupun menengah yang harus memenuhi syarat-syarat tertentu.

Dengan demikian, terlihat bahwa poisi pekerja rumahan, khususnya yang bekerja pada PT Ara Shoes Indonesia berada dalam posisi yang kurang beruntung, sebagaimana diadalilkan oleh John Rawls. Penerapan pola usaha kemitraan yang mencoba menyimpang dari ketentuan Undangundang Ketenagakerjaan, telah melenceng dari tujuan kemitraan yang erat kaitannya dengan kesetaraan dalam berusahan dan pemberdayaan 
yang dilakukan oleh usaha besar kepada usahausaha yang lebih kecil. Keadaan ini, alih-alih disebut kemitraan, merupakan bentuk dari perbudakan modern (modern slavery) yang menciptakan ketimpangan ekonomi. Untuk itu, diperlukan pengaturan ataupun tindakan untuk mengatasi kondisi ketidak-beruntungan yang dialami oleh pekerja rumahan sebagaimana dikonsepkan oleh John Rawls dalam justice as fairness.

\section{Pemenuhan Hak-hak Pekerja Rumahan melalui Mobilisasi Undang-undang Ketenagakerjaan}

Sampai saat ini, belum ada data pasti mengenai jumlah pekerja rumahan di Indonesia. Badan Pusat Statistik (BPS) tidak pernah melakukan pendataan secara khusus kepada pekerja rumahan. Terbukti dari tidak adanya kolom pekerja rumahan dalam data statistik yang kerap dipublikasikan oleh BPS. Besar kemungkinan, hal ini dikarenakan belum adanya pemahaman bahwa pekerja rumahan adalah pekerja. Hal ini menjadi salah satu faktor rentannya posisi pekerja rumahan.

Empat non-government organization (NGO) yang selama ini aktif mendampingi pekerja rumahan, yaitu Mitra Wanita Pekerja Rumahan Indonesia (MWPRI) di Malang, Yayasan Bitra Indonesia di Medan, Trade Union Right Centre (TURC) di Jakarta dan Yayasan Annisa Swasti (YASANTI) di Yogyakarta dan Jawa Tengah saat ini mendampingi sebanyak 4.778 orang pekerja rumahan (MAMPU, 2018). Jumlah ini merupakan jumlah yang cukup besar mengingat hanya dilakukan oleh empat NGO, yang bekerja tidak hanya untuk melakukan pendataan, namun juga pendidikan dan advokasi.

Lemahnya perlindungan terhadap hak-hak pekerja rumahan juga diafirmasi dengan minimnya aplikasi hukum ketenagakerjaan untuk melindungi pekerja rumahan. Sebagai contoh, Lembaga Bantuan Hukum (LBH) Semarang mencatat, kasus PHK oleh PT Ara Shoes Indonesia yang dialami Giyati sempat dinyatakan oleh Dinas Tenaga Kerja Kabupaten Semarang bukan sebagai kasus perselisihan hubungan industrial dengan alasan pekerja rumahan bukan merupakan pekerja dan tidak ada hubungan kerja antara pekerja rumahan dengan perusahaan (LBH Semarang, 2018).

Sementara, dalam penelitian yang telah lakukan, terlihat adanya upaya dari PT Ara Shoes Indonesia untuk mensiasati hukum ketenagakerjaan, yaitu dengan membuat Perjanjian Kemitraan antara perusahaan dan pekerja rumahan Padahal, perjanjian tersebut merupakan perjanjian baku dan terdapat klausul yang menyatakan bahwa pekerja rumahan diharuskan tunduk dan melaksanakan seluruh ketentuan yang telah diatur dalam tata tertib maupun ketentuan lain yang menjadi keputusan Direksi atau Manajemen perusahaan. Oleh karenanya, alih-alih berposisi sebagai mitra yang seharusnya setara, pekerja rumahan ditempatkan pada posisi subordinat dari perusahaan.

Posisi rentan atau tidak beruntung yang dialami oleh pekerja rumahan perlu disoroti dalam perspektif justice as fairness. Pada prinsip (2)a justice as fairness, dinyatakan bahwa ketimpangan sosial dan ekonomi mesti diatur sedemikian rupa, 
Jurnal Pembangunan Hukum Indonesia

Volume 1, Nomor 2, Tahun 2019
Program Studi Magister IImu Hukum Fakultas Hukum Universitas Diponegoro sehingga diperoleh manfaat sebesar-besarnya bagi anggota masyarakat yang paling tidak beruntung.

Hal ini sejalan dengan cita keadilan sosial sebagaimana diamanatkan oleh sila kelima Pancasila. Pengaturan ini dimaksudkan untuk menciptakan kesempatan yang lebih merata dari apa yang ada dalam struktur masyarakat dan untuk menciptakan persamaan outcome yang dapat menanggulangi ketidakmerataan yang terjadi (Asshiddiqie, 2011).

Meskipun hak-hak pekerja rumahan telah dijamin dalam Undang-Undang Ketenagakerjaan, namun dalam kenyataannya pekerja rumahan masih belum terpenuhi hak-haknya. Oleh karena itu diperlukan mobilisasi hukum, karena sebagaimana disampaikan oleh Black, "Without mobilization of the law, legal control system lies out of touch with the human problems it is designed to oversee".

Mobilisasi hukum ini diperkuat dengan imperatif konstitusi melalui Pasal 27 ayat (2) dan Pasal 28D ayat (2) yang pada intinya menegaskan bahwa setiap orang berhak atas pekerjaan serta perlakuan yang adil dan layak dalam hubungan kerja. Dan kemudian, dilakukan penafsiran sistematis terhadap Undang-Undang Ketenagakerjaan.

Mobilisasi hukum, dinyatakan oleh Black memiliki struktur sebagai berikut: (1) legal inteligence; (2) the availabilty of law; (3) the organization of discretion; dan (4) legal change. (Black, 1973). Mengingat telah adanya UndangUndang Ketenagakerjaan, maka yang perlu dilakukan cukup melalui struktur pertama.
Berkenaan dengan legal intelegence atau penyelidikan hukum, dilakukan melalui, "How the mobilization of law is organized has profound consequences for the discovery of illegality". Untuk menemukan pelanggaran tersebut, telah terdapa dasar hukum yang cukup kuat dalam hukum ketenagakerjaan, yaitu pada Pasal 102 ayat (1) Undang-Undang Ketenagakerjaan yang menyatakan, "Dalam melaksanakan hubungan industrial, pemerintah mempunyai fungsi menetapkan kebijakan, memberikan pelayanan, melaksanakan pengawasan, dan melakukan penindakan terhadap pelanggaran peraturan perundang- undangan ketenagakerjaan". Artinya, pemerintah diharuskan proaktif dalam menemukan pelanggaranpelanggaran hak-hak pekerja rumahan melalui Pengawas Ketenagakerjaan. Adapun pengaturan tata cara pengawasan ketenagakerjaan terdapat dalam Peraturan Menteri Tenaga Kerja Nomor 33 Tahun 2016 tentang Tata Cara Pengawasan Ketenagakerjaan.

Dengan demikian, pemenuhan mengenai hakhak pekerja rumahan dapat dilakukan sebagaimana teori justice as fairness.

\section{SIMPULAN}

Pekerja rumahan merupakan subjek dalam hukum ketenagakerjaan karena telah memenuhi definisi sebagai pekerja. Selain itu, juga terdapat hubungan kerja antara pekerja rumahan dengan perusahaan meskipun diklaim oleh perusahaan sebagai hubungan kemitraan. Dengan demikian, hakhak normatif pekerja sebagaimana diatur dalam 
Undang-Undang Ketenagakerjaan juga menjadi hakhak dari pekerja rumahan.

Praktik pola usaha kemitraan yang digunakan oleh PT Ara Shoes Indonesia kepada pekerja rumahan tidak memiliki dasar hukum karena tidak memenuhi kriteria kemitraan sebagaimana dimaksud dalam Undang-Undang Nomor 20 tahun 2008 tentang Usaha Mikro, Kecil, dan Menengah. Kemudian, upaya PT Ara Shoes Indonesia untuk membuat perjanjian kemitraan dengan pekerja rumahan dapat dikategorikan sebagai misbruik van omstandigheden karena menyalahgunakan keadaan, dalam hal ini keunggulan ekonomi. Selain itu, tidak terdapat substansi kemitraan sebagaimana diatur dala Perjanjian Kemitraan antara PT Ara Shoes Indonesia dengan pekerja rumahan karena pekerja rumahan berada dalam posisi subordinat terhadap perusahaan.

Penerapan pola usaha kemitraan tersebut juga berdampak pada terlanggarnya hak-hak pekerja rumahan, yaitu: (1) Terjadinya diskriminasi kepada pekerja rumahan dalam hubungan kerja; (2) Tidak disediakannya jaminan sosial oleh perusahaan, (3) Rendahnya upah bahkan kurang dari setengah jumlah UMK sementara jam kerja relatif sama, dan (4) Tidak adanya jaminan K3. Artinya, telah terjadi pelanggaran terhadap Undang-Undang Ketenagakerjaan dan juga pengabaian mandat UUD NRI 1945.

Untuk itu, dalam rangka pemenuhan hak-hak pekerja rumahan dengan didasari justice as fairness dan penfsiran sistsematis atas Undang-Undang Ketenagakerjaan, diperlukan mobilisasi hukum ketenagakerjaan. Dengan merujuk kepada Pasal 102 ayat (1) Undang-Undang Ketenagakerjaan dan Peraturan Menteri Tenaga Kerja Nomor 33 Tahun 2016 tentang Tata Cara Pengawasan Ketenagakerjaan, instansi yang bertanggungjawab dalam urusan ketenagakerjaan harus melakukan legal inteligence sebagaimana dimaksud Donald $\mathrm{J}$. Black. Dengan demikian, diskriminasi pemenuhan hak-hak pekerja rumahan yang selama ini terjadi kepada pekerja rumahan dapat diatasi

\section{DAFTAR PUSTAKA}

\section{BUKU}

Asshiddiqie, J. (2009). Pengantar IImu Hukum Tata Negara. Jakarta: Raja Grafindo Persada.

Benería, Lourdes., \& Floro, Maria. (2005). Distribution, gender, and labor market informalization: A conceptual framework with a focus on homeworkers. In Kudva, Neema \& Beneria, Lourdes (eds), Rethinking Informalization: Proverty, Precarious J obs and Social Protection. Cornell University Open Acces Repository.

LBH Semarang. (2018). Catatan Akhir Tahun LBH Semarang 2018: Ruang Gelap Demokrasi. Semarang: LBH Semarang.

Voss, Guus H. (2012). Kesepakatan/Perjanjian Kerja. In Voss, G.H. \& Tjandra, S. (Eds.), Bab-bab Tentang Hukum Perburuhan di Indonesia ( $p$. 14). Bali: Pustaka Larasan. 
Jurnal Pembangunan Hukum Indonesia

Volume 1, Nomor 2, Tahun 2019
Program Studi Magister Ilmu Hukum Fakultas Hukum Universitas Diponegoro

\section{JURNAL}

Alwino, A. (2016). Diskursus Mengenai Keadilan Sosial: Kajian Teori Keadilan dalam Liberalisme Locke, Persamaan Marx, dan Justice as Fairness Rawls. Melintas, Vol.32, (No.3), pp. 323-324.

Asshiddiqie, J. (2011). Pesan Konstitusional Keadilan Sosial. J urnal Keadilan Sosial, (Edisi II/ 2011), p. 37.

Arnold, Dennis., \& Bonglovi, Joseph. (2013). Precarious, Informalizing, and Flexible Work Transforming Concepts and Understandings. American Behavioral Scientist, (Vol. 57, No. 3, Maret 2013), p. 301.

Dutta, S. (2017). Rawl's Theory of Justice: An Analysis. Journal of Humanities and Social Science, Vol. 22 (Issued 4, Ver. 1, April 2017), p. $40-43$.

Fattah, D. (2013) Teori Keadilan Menurut John Rawls. Jurnal TAPIS, Vol.9, (No.2,JuliDesember 2013), p. 35.

Juliawan, Benny H. (2010). Extracting Labor From Its Owner. Critical Asian Studies, Vol.42, (No.1), p. 28.

Paparang, F. (2016). Misbruik van Omstandigheden dalam Perkembangan Hukum Kontrak. Jurnal Hukum Unsrat, Vol.22 (No.6, Juli 2016), pp. 57-58.

Sofiani, T. (2010). Eksistensi Perempuan Pekerja Rumahan dalam Konstelasi Relasi Gender. Muwazah, Vol. 2 (No. 1, Juli 2010), p.198.
Tjandraningsih, I. (2012). State-Sponsored Precarious Work in Indonesia. American Behavioral Scientist, Vol.XX, (No.X), p. 2.

\section{SUMBER ONLINE}

MAMPU: Kemitraan Australian - Indonesia untuk Kesetaraan Gender dan Pemberdayaan Perempuan, (2018). Mitra MAMPU Adakan Konsolidasi untuk Tingkatkan Perlindungan Pekerja Rumahan Perempuan. Diperoleh dari http://mampu.or.id/cerita-

perubahan/cerita/pentingnya-pengakuan-danperlindungan-bagi-pekerja-rumahan-diindonesia/, diakses pada 28 Februari 2019.

\section{WAWANCARA}

Giyati, Mantan Pekerja Rumahan PT Ara Shoes Indonesia Nomor Induk 801194, pada tanggal 15 Oktober 2018.

Rima Astuti, Staf Yasanti - Kantor Ungaran, pada tanggal 14 Februari 2019. 